UDC: 796: 658

DOI: https://doi.org/10.26661/hst-2020-5-82-12

\title{
SUSTAINABILITY EVALUATION OF SPORTS EVENTS ORGANIZED IN LITHUANIA
}

\author{
(C) SKIRMANTAS, SINKEVIČIUS \\ Lithuanian Sports University (Kaunas, Lithuania) \\ E-mail: skirmantassink@gmail.com \\ ORCID iD: https://orcid.org/0000-0002-8613-3888 \\ Каунаський університет спорту, 6 , Каунаський повіт, 44221 Каунас, Литва \\ Lithuanian Sports University, 6, str. Sporto, Kaunas municipality, 44221 Kaunas, \\ Lithuania \\ (C) SVAGZDIENE, BIRUTA \\ Lithuanian Sports University (Kaunas, Lithuania) \\ E-mail: biruta.svagzdiene@lsu.lt \\ ORCID iD : https://orcid.org/0000-0001-6016-6019 \\ Каунаський університет спорту, 6 , Каунаський повіт, 44221 Каунас, Литва \\ Lithuanian Sports University, 6, str. Sporto, Kaunas municipality, 44221 Kaunas, \\ Lithuania
}

\begin{abstract}
Abstarct
The relevance of this study. Sport is for the most part a enjoyable experience, attracting billions of people to games, events Sports events generate a huge amount of rubbish, from packaging, plates and bottles to food waste. Lithuania still has a significant number of organizers who have not given up disposable plastic utensils at their sporting events. The aim of this study was to assess the sustainability of sports events organized in Lithuania. The main problem remains that most sports events in Lithuania do not give up and use disposable tableware. Since January, the capital's council has taken an extraordinary decision - from 2020. No disposable plastic utensils will be used at the events taking place in Vilnius in March. The objectives of the study are: to reveal the meaning of sustainability of sports events in the theoretical aspect. Identify the factors and quantities that determine the generation of plastic waste. To study the contribution of sports events organized in Lithuania to environmental sustainability. The findings showed that during 2019 and 2020, 151 thousand disposable cups, 30 thousand $0.5 \mathrm{l}$ bottles and 47 thousand pieces of other waste were generated. The used methodology is justified - scientific literature analysis. Non-standardized review interview. Questionnaire survey. Quantitative data analysis. Sports events of 6 different organizers were studied. Data for the last two years $(2019,2020)$ were analyzed. An additional online survey included 117 respondents.
\end{abstract}

Key words: sustainability, sporting events, plastic, reusable tableware.

\section{Statement of the problem.}

The problem is that there is a lack of sustainability and a high level of consumerism in the organization of sporting events. The sports sector has undergone changes as organizations at all levels have begun to attach great importance to becoming greener [1]. A major sustainability and ecological issue is that sporting events produce a lot of rubbish. At the Summer Olympics in Athens, half a million tonnes were produced in two weeks roughly similar to what a city of 1 million people would emit in a similar period. 2017 About 62,000 disposable water bottles and 1.4 million cups of water were used during the Boston Marathon. 2018 At the London Marathon, Westminster City Council 
collected $5,200 \mathrm{~kg}$ of rubbish and $3,500 \mathrm{~kg}$ of materials for recycling, of which there were 47,000 plastic bottles on the street [2]. In Lithuania, we still have a large number of organizers who have not given up disposable plastic utensils at their sports events. Since January, the capital's council has taken an extraordinary decision - from 2020. No disposable plastic containers will be used at the events taking place in Vilnius in March. This solution will help reduce the amount of plastic waste in the city and educate citizens about waste management. The largest organizers of hiking in the Baltic States, ,TrenkTuras“ (Event A), have decided to become an ecological and sustainable event since February 2020 - they have completely given up disposable tableware. Sustainable development is a constant concern for researchers in both tourism [3] and sports [4]. Despite the increasing focus in these key areas, little effort has been made to articulate or theoretically and empirically address critical issues related to the ways in which sport and tourism interact in the context of sustainability. It is increasingly recognized that tourism systems are established in the broader social, cultural, political, and economic dimensions of sustainable development [5]. This work shows how much sporting events generate solid waste and how some organizers try to prevent this by applying the principles of responsible consumption.

\section{Analysis of recent studies and publications}

The relationship between sport and the natural environment is bidirectional; that is, sport impacts the natural environment and is impacted by the natural environment. Since the 1990s, sport management scholars have predominantly explored the ways the sport industry impacts the natural environment. They have done so through the lenses of sport sustainability [6]; [7]; [8], corporate social responsibility [9]; [10]; [11]; [12]; [1], and sport industry's influence on proenvironmental behaviors [13]; [14]. Recently, a new line of research has emerged, exploring the impacts of climate change on the sport industry [15]; [16] and adaptation behaviors of athletes, organizations, and fans [17].

Objective of the article was to assess the sustainability of sports events organized in Lithuania.

\section{Main Material}

The relationship between sport and the natural environment is two-way; it is a sport that affects the natural environment and is affected by the natural environment. Since the 1990s, sports management researchers have mainly researched how the sports industry affects the natural environment. They have done so through objective goals of the sustainability of sport, corporate social responsibility and the influence of the sports industry on environmental behavior. Recently, a new line of research has emerged examining the effects of climate change on the sports industry. Until now, research on sport and the natural environment have not been separated, they have been combined only by 
literature reviews, academic or silenced lines of research. This lack of cohesion runs counter to other subdisciplines of sports management, such as sports marketing and sports tourism, which are widely recognized for their value, special coursework and recognition within and between academic communities. The lack of cohesion can be explained by insufficient research or interest, or by the fact that the state of the environment has been taken for granted in the past [18].

Sustainability is the decision and choice of how to mitigate the negative consequences and impacts of human actions, and then take action to use resources wisely, fairly, and equitably for both the present and future generations [19]). The 1992 World Summit in Rio de Janeiro set out the basic principles for sustainable development. Attitudes towards sustainable tourism have changed since the Journal of Sustainable Tourism was first published in 1993 [20].

The most commonly used definition of sustainability was included in the World Commission on Environment and Development's report "Our Common Future", which defined sustainable development as "meeting the needs of the present without compromising the ability of future generations to meet their own needs". This definition implies a free link between the economy of sustainability and prosperity and has a positive connotation [18].

The concept of a sporting event. Events largely depend on three components: the organizing organ; venue for the event; and audience. The event management team, the host community and the event visitors are all necessary for the management of the event between the event community, the host community and the visitors, but equally dependent on the allocation and allocation of resources, including human resources, infrastructure and funds.

- Human resources. Human resources are key aspects of event management. Many events are organized in a more or less formal event organization system, with a management team including temporary staff, volunteers, and more. Secondly, the human resources of the host community are also important. Events require people directly or indirectly involved as suppliers of products and services, people providing public services, local politicians and local people who not only represent a potential audience but whose consent and support are essential to the success of the event. Third, events depend on human resources, such as visitors, locals, and / or international visitors actively participating in the event.

- Infrastructure. While the event industry confirms that people can achieve a lot for little or no reward (e.g., volunteers), infrastructure will always be needed. In addition to the natural environment, the necessary infrastructure includes venues providing a physical platform for the event, roads and airports providing access, as well as services such as parking, electricity and waste management. Even events in 
cyberspace depend on infrastructure such as the Internet and computers.

- Funds. While some events are more expensive to choose than others, most of them depend on minimal financial resources for marketing, licensing, insurance, taxes, and more. In addition, few events can increase or maintain momentum without financial resources. Funding is usually provided through event owners, paying participants, private sector sponsors and / or government through public resources.

Therefore, the main task of the event manager is based on the following concept: by mobilizing and allocating resources

(human resources, infrastructure and funds), to create a program that supports the support of various stakeholders and custodians [21].

Planning sporting events can be quite challenging, given the number of decisions made and the number of people involved in those decisions. Specifically, several stakeholders are involved (local organizing committees, participants, sanctioning bodies, premises, sponsors, etc.), and several tasks have to be performed (such as logistical planning, marketing, and leadership) [22].

\begin{tabular}{|l|l|}
\hline Event phase & Tasks \\
\hline Event development phase & Event is envisioned. Event organization is created \\
\hline $\begin{array}{l}\text { Event operational planning } \\
\text { phase }\end{array}$ & $\begin{array}{l}\text { Internal and external environments are analyzed. } \\
\text { Goals and objectives are set. } \\
\text { Key decisions are made. }\end{array}$ \\
\hline $\begin{array}{l}\text { Event implementation, } \\
\text { monitoring, and management } \\
\text { phase }\end{array}$ & $\begin{array}{l}\text { Resources are gathered and allocated. } \\
\text { Staff are trained. } \\
\text { Activities are managed. }\end{array}$ \\
\hline $\begin{array}{l}\text { Event evaluation and } \\
\text { renewal phase }\end{array}$ & $\begin{array}{l}\text { Results are matched to objectives. } \\
\text { Plans are modified based on results. }\end{array}$ \\
\hline
\end{tabular}

Table 1. Event Planning Model [22]

From Table 1. we see that events go through several stages, and event planning plays different roles at each stage. In the planning phase, the members of the organizing group take action to make their vision a reality. After a thorough situation analysis of the organization and the environment, they determine the goals and objectives of the event. In addition, it is at this stage that detailed information is provided on what needs to be done to achieve these goals and objectives. The main areas of decision in the planning phase include the name and theme of the event, the program or schedule of events, the time and duration, and the location. These decisions will lead to more budgetary and staffing decisions [23].

At first glance, the events seem to be the opposite of sustainability - they are short-lived, involve the mass movement of thousands of people and can disrupt existing site plans. It should be remembered that this applies to large events and that smaller events will not have the same unsustainable features. However, there is hope that even the most important events can overcome these problems and lead to sustainable regeneration effects. By applying some of the lessons of 50 years of 
experience, cities can use them to achieve urban renewal that adheres to the basic principles of sustainable development. Ultimately, this means following good regeneration practices, while using the key strengths of events - their ability to excite and inspire - to promote levels of support and participation that would not be possible without event associations [24].

Given the scale and relevance of environmental issues around the world and the wealth of research involved, it is easy to see why calls for "sustainability," especially for organizations, have become commonplace in recent decades [25]. It is therefore not difficult to see why there are serious reasons to believe that such environmental problems, and in particular their causal link, also have a significant impact on sport, sports organizations and their managers.

The importance of the relationship between the natural environment and sports organizations is increasingly recognized by both governmental sports agencies and non-governmental organizations [26]; [27]; [28]; [29]; [30]; [31]. Two main features of this non-academic literature are distinguished. First, they are based on the recognition that sports organizations, competitions and events contribute directly and indirectly to global and local environmental problems, and that this undermines the 'sustainability' of natural ecosystems, the so-called 'natural environment'. As a result, the concept of sustainability is increasingly seen by governments as sports agencies and non-governmental organizations as a legitimate and important concern of sports organizations and the stakeholders they work with.

Sports organizations have recently begun to pay close attention to environmental sustainability, in line with industry trends and policies aimed at making the sports sector more sustainable [32]. Accordingly, higher education in sports management, as a key stakeholder in the sports sector, training future professionals to ideally develop sport in a sustainable way, has recognized the need to integrate environmental sustainability into curricula [33]. This can help future professionals improve their skills and have the tools to manage the impact of sport on the environment.

In order for organizations to achieve sustainability in their operations, they must rely on a phase model of sustainability. The model encompasses six phases spread over three waves of sustainability and is described as a tool for comparing organizations' commitments and practices for human and environmental sustainability. The six stages are:

1) rejection - when an organization deliberately rejects attempts to achieve sustainability for financial gain;

2) non-response - when an organization is unsustainable due to lack of awareness rather than explicit rejection;

3) "compliance" means the reduction of the risk of sanctions for 
non-compliance with minimum standards;

4) "efficiency" means the pursuit of a competitive advantage through the initiation of sustainable practices;

5) strategic activity - when sustainability is an important part of the organization's strategy;

6) supporting corporation - where senior management has "strongly established" the goal of achieving a sustainable world (25].

Plastic waste generation and determinants at a sporting event

Plastics are polymeric compounds obtained by polymerizing small molecular organic compounds such as ethylene, styrene, etc., and can be broadly classified into thermoplastic and thermosetting plastics. Since the original invention of plastics, various plastic products have become excellent substitutes for traditional materials such as paper, wood, metal and ceramics in various manufacturing industries due to their advantages of light weight, high strength, good insulation, high transparency, excellent corrosion resistance, low cost and ease [35]. Current world production is estimated at around 300 million tonnes and is expected to increase by 2050 . It will reach 500 million tons, and most of it will be disposable products. One of the activities that generates a large amount of solid waste is sports events, where waste increases as the number of spectators increases [35].

The 2018 London Marathon was the hottest, but it was also unique in that organizers tested the use of compostable cups to reduce the number of plastic bottles that usually litter the streets after an event. Approximately 90,000 cups as well as 760,000 plastic bottles for runners were built at the three drinking stations along the route. After the competition, all bottles had to be recycled and the cups composted [36].

The UK government has invested around $€ 61.4$ million. Pounds to keep plastic waste out of the ocean are also planning to ban plastic straws and cups, which are common products at sporting events. However, this is only the first step of the Government in helping to overcome the plastic waste crisis and there may be even more in the future. As a result, this issue has become a new challenge not only for sporting event managers but also for managers and participants themselves [37].

The generation of plastic waste at a sports event depends on the organizers' approach to the use of disposable packaging. Some organizers are still free to use plastic bottles and cups, while others are abandoning them, thus contributing to the ecology and sustainability of sporting events. Of course, the awareness of the participants and the perseverance and diligence of the volunteers who collect and take care of the garbage collection are of great importance.

Summary. Sports events of 6 different organizers were studied. Data for the last two years (2019, 2020) were analyzed. In particular, each sports event organizer was introduced to the purpose of the study, the process and the usefulness of the information provided by them for the results of the environmental 
sustainability assessment, finding out how much and what disposable or reusable containers and containers are used during sports events. The obtained data can be seen in Figure 1 and
Figure

\section{Number of units}

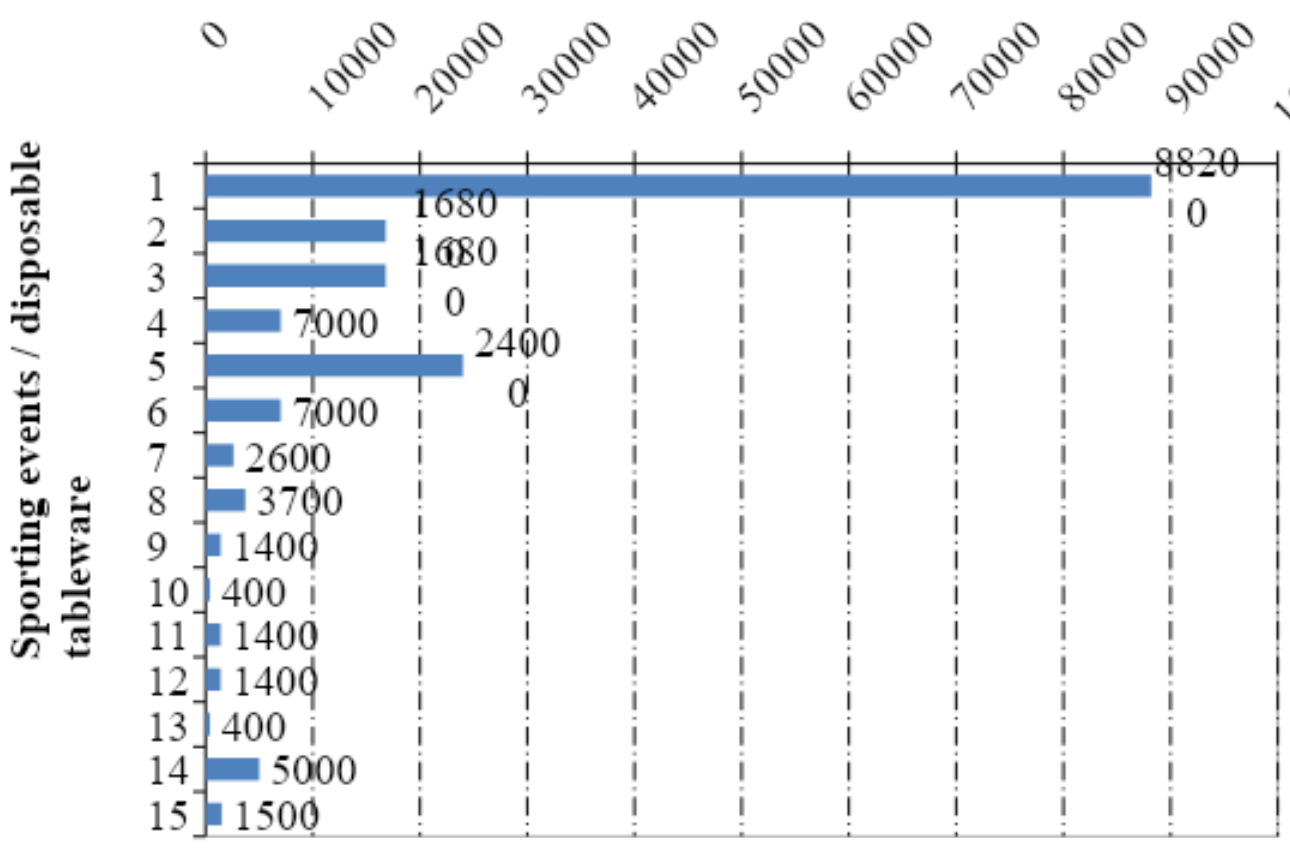

Figure 1. 2019 the number of disposable items used in units

Fig. 1 data on items used in 2019 are presented at six sporting events, as this year all events used disposable items.

Number of units

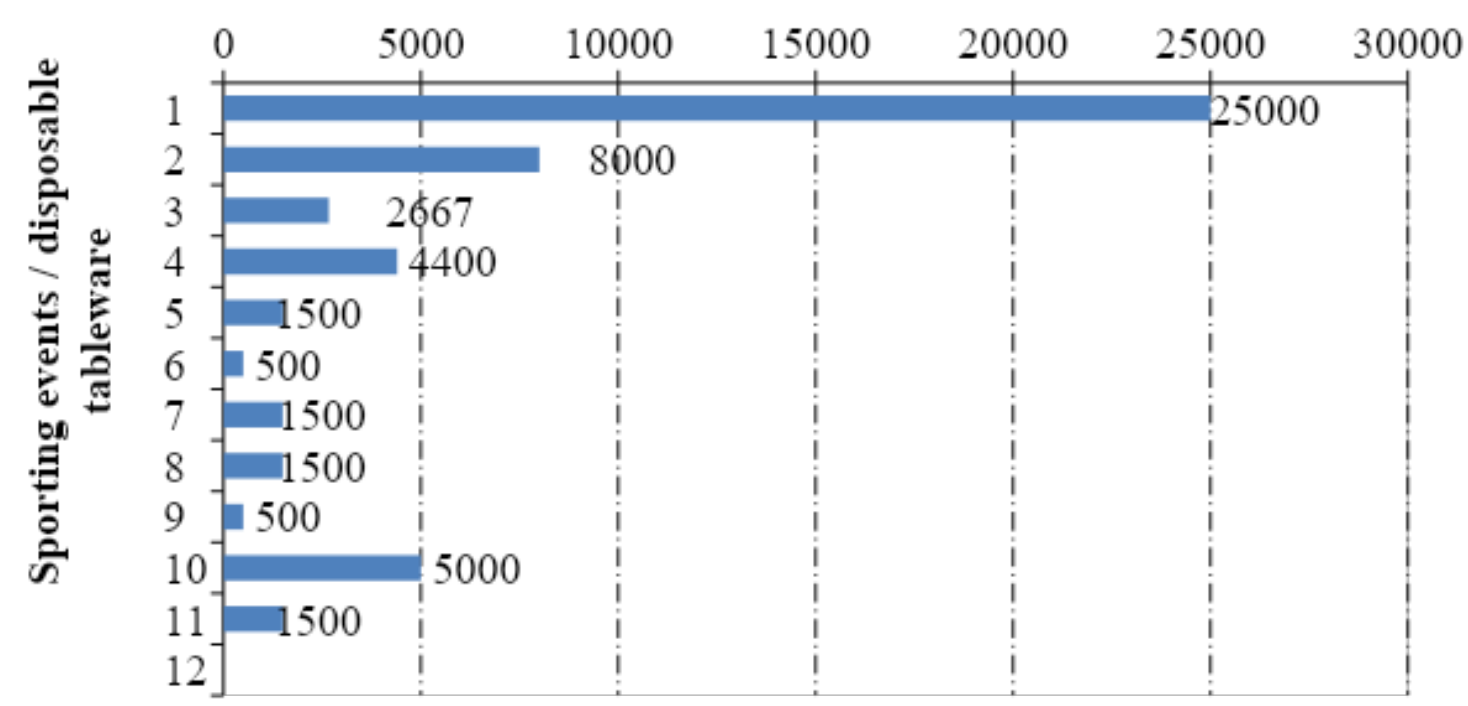

Figure 2. 2020 the number of disposable items used in units

Fig. 2 we see that in 2020, TrenkTuras (Event A) abandoned disposable items and started using reusable items, thus contributing to the improvement of environmental sustainability.

After statistically processing the anonymous survey was conducted in data obtained, an additional online, order to find out if participants would 
pay more if they knew that reusable event.

utensils would be used during the

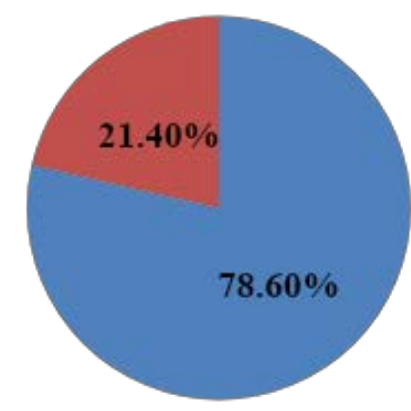

Agree

Disagree

Figure 3. Percentage distribution of respondents to support the idea that the use of disposable tableware at sporting events should be abandoned

Figure 3 shows that the majority of of disposable tableware at sporting respondents $\quad(78.60 \%$ of 92 events, the rest $(21.40 \%$ of 25 respondents) would support a waiver respondents) disagree.

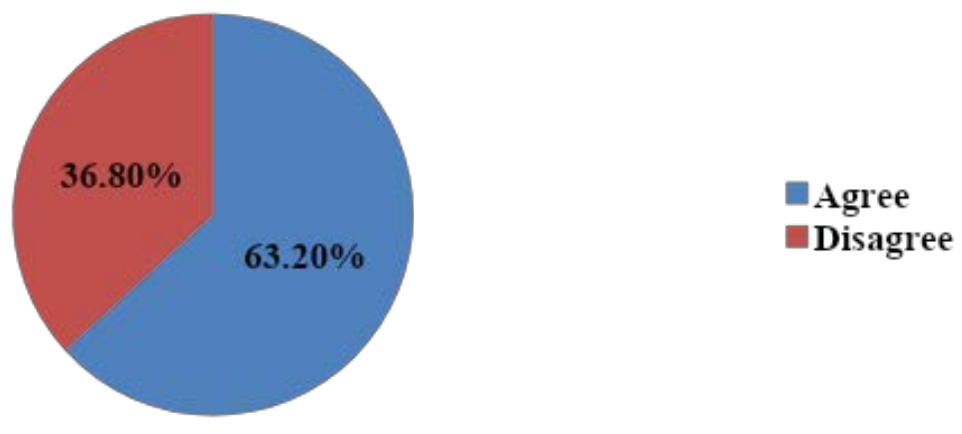

Figure 4. Survey participants' opinion on agreeing to pay more than usual for a ticket if reusable tableware is used at the event

According to Figure 4, we see that the majority $(63.20 \%$ of 74 respondents) would still agree to pay more than usual for a sporting event, in order to make it more sustainable, a small proportion $(36.80 \%$ of 43 respondents) would still agree. would not agree to pay more for the ticket.

The data in Figure 5 show that the majority (41.30\% of 49 respondents) would be willing to pay $€ 1$ more for a ticket to a sporting event than usual, although the percentage of those who would pay $€ 2$ more is not low after the other ( $20.80 \%$ of 24 respondents). $37.90 \%$, consisting of 43 respondents, would pay the minimum amount reported in the survey. These results show that if sports organizers increased the normal price of an event, they could give up disposable utensils and switch to multiple rentals, which are more expensive, but would not lead to a reduction in revenue, but contribute much more to environmental sustainability. 


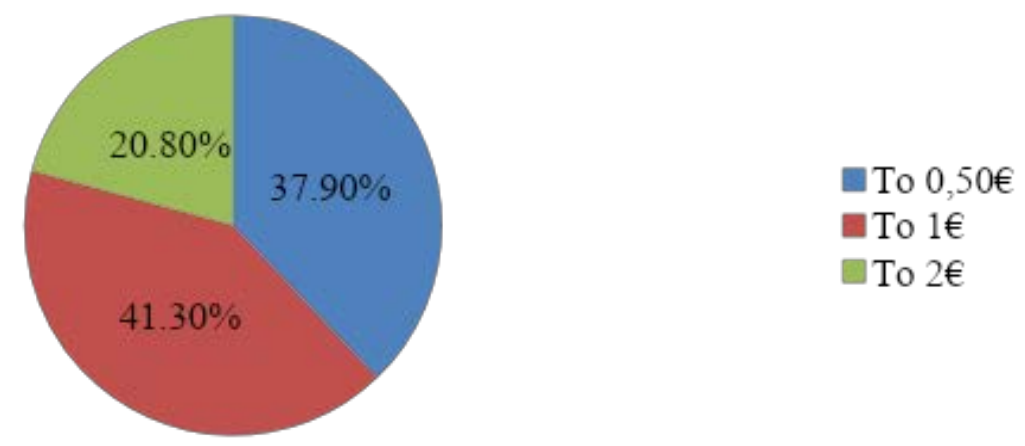

Figure 5. Distribution of survey participants according to the amount they would be willing to pay more for a sporting event knowing that it will use reusable tableware

This suggests that sports event organizers could contribute to TrenkTuras sustainability initiative by moving away from disposable tableware and switching to reusable ones, thus reducing the consumption of large quantities of disposable tableware, which often generates a lot of waste and is discarded after sporting events.

Conclusions there has been a lot of rhetoric over the last decade about the need for sustainability, and the crucial importance of this issue has only become apparent in the last couple of years, given that the challenges of climate change have become apparent. It is important to monitor the results of sustainabilityoriented sporting events and then to fully manage the environmental impact of such events. The main factor determining the generation of solid waste during sports events is the satisfaction of human physiological needs. What in the fairy tale during 2019/2020 amounted to 151 thousand. Disposable glasses. 30 thousand 0.51 bottles and 47 thousand. units of other waste. TrenkTuras, the only organizer in Lithuania, has been using reusable containers during the event since 2020, thus contributing to environmental sustainability. Due to this idea alone, about 63,000 plastic disposable cups were not released into the environment.

Sustainability is one of the most pressing challenges of our time on a wide range of social, environmental and economic issues. Major challenges such as climate change, economic inequality and social injustice affect people all over the world. It is also a major concern for the sports community and a responsibility towards young people and future generations. We also recognize that sport has an unparalleled ability to motivate and inspire many people. That is why Lithuanian sports event organizers need to take the initiative and make alternative decisions on pollution, as the TrenkTuras event has done with the reusable use of products. However, sporting events can be part of the problem - the generation of huge amounts of plastic waste. In addition, we have a great opportunity 
to harness the power of sport to action for the environment. encourage millions of fans to take

\section{REFERENCES}

1. Trendafilova, S., \& McCullough, B. P. (2018). Environmental sustainability scholarship and the efforts of the sport sector: A rapid review of literature. Cogent social sciences. 4(1) 1467256.

2. Puangmanee, S., \& Saearlee, M. (2020). Solid waste management at an international full-marathon running event in southern thailand. WIT Transactions on Ecology and the Environment. 247. 35-45.

3. McCool, S. (2015). Sustainable tourism: Guiding fiction, social trap or path to resilience. Challenges in tourism research. 224-234.

4. Taks, M. (2013). Social sustainability of non-mega sport events in a global world1. European Journal for Sport and Society. 10(2). 121-141.

5. Bramwell, B., Higham, J. E. S., Lane, B., \& Miller, G. (2017). Twenty-five years of sustainable tourism and the Journal of Sustainable Tourism: Looking back and moving forward. Journal of Sustainable Tourism. 25(1).

6. Mallen, C., \& Chard, C. (2012). "What could be" in Canadian sport facility environmental sustainability. Sport Management Review. 15(2). 230-243.

7. Kellison, T. B., \& Hong, S. (2015). The adoption and diffusion of pro-environmental stadium design. European Sport Management Quarterly. 15(2). 249-269.

8. Mallen, C., Adams, L., Stevens, J., \& Thompson, L. (2010). Environmental sustainability in sport facility management: A Delphi study. European Sport Management Quarterly. 10(3). 367-389.

9. Casper, J., Pfahl, M., \& McSherry, M. (2012). Athletics department awareness and action regarding the environment : A study of NCAA athletics department sustainability practices. Journal of Sport Management. 26(1). 11-29.

10. Inoue, Y., \& Kent, A. (2012). Sport teams as promoters of pro-environmental behavior: An empirical study. Journal of Sport Management. 26(5). 417-432.

11. Inoue, Y., \& Kent, A. (2012). Investigating the role of corporate credibility in corporate social marketing : A case study of environmental initiatives by professional sport organizations. Sport Management Review. 15 (3). 330-344.

12. Kellison, T. B., \& Kim, Y. K. (2014). Marketing pro-environmental venues in professional sport: Planting seeds of change among existing and prospective consumers. Journal of sport management. 28 (1). 34-48.

13. Casper, J. M., McCullough, B. P., \& Pfahl, M. E. (2020). Examining environmental fan engagement initiatives through values and norms with intercollegiate sport fans. Sport Management Review. 23(2). 348-360.

14. Trail, G. T. (2016). Sport consumer behaviour. Routledge handbook of theory in sport management. 225-236.

15. Dingle, G. W., \& Stewart, B. (2018). Playing the climate game: climate change impacts, resilience and adaptation in the climate-dependent sport sector. Managing Sport and Leisure. 23(4-6). 293-314.

16. Orr, M., \& Inoue, Y. (2019). Sport versus climate: Introducing the climate vulnerability of sport organizations framework. Sport Management Review. 22(4). 452-463.

17. Orr, M., \& Schneider, I. 2018. Substitution interests among active-sport tourists : The case of a cross-country ski event. Journal of Sport \& Tourism, 22(4), 315-332.

18. McCullough, B. P., Orr, M., \& Kellison, T. (2020). Sport ecology: Conceptualizing an emerging subdiscipline within sport management. Journal of Sport Management. 1(aop). 1-12.

19. Pan, B., Huan, T. C., \& Yuan, Y. Y. (2013). Adding environmental sustainability to the management of event tourism. International Journal of Culture, Tourism and Hospitality Research.

20. Bramwell, B., \& Lane, B. (1993). Sustainable tourism : An evolving global approach. Journal of sustainable tourism. 1(1). 1-5.

21. Raj, R., \& Musgrave, J. (Eds.) (2009). Event management and sustainability. Cabi. 
22. Greenwell, T. C., Danzey-Bussell, L. A., \& Shonk, D. J. (2019). Managing sport events. Human Kinetics.

23. Mallen, C., L.J. Adams (2008). Sport, recreation and tourism event management: Theoretical and practical dimensions. Oxford : Elsevier

24. Masterman, G. (2014). Strategic sports event management. Routledge.

25. Benn, S., Dunphy, A. P., \& Griffiths, A. (2014). Organizational change for corporate sustainability (3rd ed.). London, U.K. : Routledge.

26. GSA (2014). Green Sports Alliance. Retrieved 26 September, 2014, from http://greensportsalliance.org/

27. IOC (2012). Sustainability through sport: Implementing the Olympic Movement's Agenda 21 (pp. 102). Geneva, Switzerland: International Olympic Committee.

28. IOC (2014). IOC Sport and Environment Commission. Retrieved 26 September, 2014, from http://www.olympic.org/sport-environment-commission?newstab=0\&tab=3

29. UNEP (2014). UNEP launches Green Passport Initiative to reduce environmental impacts of 2014 World Cup in Brazil Retrieved 30 September, 2014, from http://www.unep.org/newscentre/default.aspx?DocumentID=2788\&ArticleID=10866

30. UNEP (2015). Impact of sport on the environment. Retrieved 26 September, 2014, from http://www.unep.org/sport_env/impactSport_Env.aspx

31. UNEP (2015). Impact of the environment on sport. Retrieved 26 September, 2014, from http://www.unep.org/sport_env/impactEnv_Sport.aspx

32. Trendafilova, S., \& Babiak, K. (2013). Understanding strategic corporate environmental responsibility in professional sport. International Journal of Sport Management and Marketing. 13(1-2). 1-26.

33. Pfahl, M. E. (2015). Teaching sport management and the natural environment. In J. M. Casper \& M. E. Pfahl (Eds.), Sport management and the natural environment: Theory and practice. 29-37. Abingdon: Routledge.

34. Wong, S. L., Ngadi, N., Abdullah, T. A. T., \& Inuwa, I. M. (2015). Current state and future prospects of plastic waste as source of fuel : A review. Renewable and sustainable energy reviews. 50. 1167-1180.

35. Atchariyasopon, K. (2017). Sustainable Solid Waste Management in Sports Events: A Case Study of Football Matches in Thailand. Journal of Population and Social Studies [JPSS]. 25(1). 69-81.

36. Pattillo, A.(2017, April 21). Is running good for the planet? Many events are going green. Competitor Running. From https://running.pocketoutdoormedia.com/runningplanetgoing-green_164017

37. University of Gloucestershire (2018). Plastic waste crisis - What can sport events managers do to produce a plastic-free sport event?

ШВАГЖДЕНЕ, БІРУТА - професор, доктор кафедри Менеджменту спорту і туризму,

Литовський університет спорту (Каунас, Литва)

E- mail: biruta.svagzdiene@lsu.lt

ORCID iD : https://orcid.org/0000-0001-6016-6019

СІНКЯВІЧЮС, СКІРМАТАС - магістр кафедри Менеджменту спорту і туризму,

Литовський університет спорту (Каунас, Литва)

Е- майл 1: skirmantassink@gmail.com

ORCID iD: https://orcid.org/0000-0002-8613-3888

\section{ОЦІНКА СТІЙКОСТІ СПОРТИВНИХ ЗАСАД, ОРГАНІЗОВАНИХ У ЛИТВІ}

Актуальність даного дослідження. Спорт в контексті своєї більшої частини приємний досвід, який залучає мільярди людей до гри, подій. Спортивні заходи генерують величезну кількість сміття, від упаковки, тарілок і пляшок для харчових відходів. У Литві як і раніше багато організаторів, які не відмовилися від одноразового пластикового посуду на своїх спортивних заходах. Метою цього дослідження була оцінка стійкості спортивних заходів, організованих в Литві. Основна проблема залишається в тому, що більшість спортивних заходів в Литві полягають в тому, щоб не здаватися і не використовувати одноразовий посуд. 3 січня столична рада прийняла позачергове рішення відносно цього питання 32020 року. На березневих заходах, які пройдуть у Вільнюсі, одноразовий пластиковий посуд (C) Skirmantas Sinkevičius, Svagzdiene Biruta, 2020 
використовуватися не буде. Цілі дослідження : розкрити значення стійкості спортивних заходів у теоретичному аспекті. Визначити чинники кількості, що визначають генерацію пластикових відходів. Вивчити вклад спортивних заходів, організованих в Литві, в екологічну стійкість. Отримані результати показали, що продовж 2019 і 2020 років було створено 151 тисяча одноразових чашок, 30 тисяч пляшок 0,5 л і 47 тисяч одиниць інших відходів. Використовувана методологія виправдана - аналіз наукової літератури: Нестандартизоване інтерв'ю для рецензованої оцінки; опитування анкет; кількісний аналіз даних. Було вивчено спортивні заходи 6 різних організаторів. Проаналізовано дані за останні два роки $(2019,2020)$. У додатковому онлайн-опитуванні взяли участь 117 респондентів.

Ключові слова: екологічність, спортивні заходи, пластик, багаторазовий посуд.

ШВАГЖДЕНЕ, БИРУТА - профессор, доктор кафедры Менеджмента спорта и туризма, Литовский университет спорта (Каунас, Литва)

E- mail: biruta.svagzdiene@lsu.lt

ORCID iD : https://orcid.org/0000-0001-6016-6019

СИНКЯВИЧЮС, СКИРМАТАС - магистр кафедры Менеджмента спорта и туризма, Литовский университет спорта (Каунас, Литва)

E- майл 1: skirmantassink@gmail.com

ORCID iD: https://orcid.org/0000-0002-8613-3888

\section{ОЦЕНКА УСТОЙЧИВОСТИ СПОРТИВНЫХ МЕРОПРИЯТИЙ, ОРГАНИЗОВАННЫХ В ЛИТВЕ}

Актуальность данного исследования. Спорт по большей части приятный опыт, привлекая миллиарды людей на игры, события Спортивные мероприятия генерировать огромное количество мусора, от упаковки, тарелки и бутылки для пищевых отходов. В Литве попрежнему много организаторов, которые не отказались от одноразовой пластиковой посуды на своих спортивных мероприятиях. Целью данного исследования была оценка устойчивости спортивных мероприятий, организованных в Литве. Основная проблема остается в том, что большинство спортивных мероприятий в Литве не сдаваться и использовать одноразовые посуды. С января столичный совет принял внеочередное решение - с 2020 года. На мартовских мероприятиях, которые пройдут в Вильнюсе, одноразовая пластиковая посуда использоваться не будет. Цели исследования: раскрыть значение устойчивости спортивных мероприятий в теоретическом аспекте. Определите факторы и количества, определяющие генерацию пластиковых отходов. Изучить вклад спортивных мероприятий, организованных в Литве, в экологическую устойчивость. Полученные результаты показали, что в течение 2019 и 2020 годов было создано 151 тысяча одноразовых чашек, 30 тысяч бутылок 0,5 л и 47 тысяч единиц других отходов. Используемая методология оправдана: анализ научной литературы; нестандартизированное интервью для рецензированной оценки; опрос анкет; количественный анализ данных. Были изучены спортивные мероприятия 6 различных организаторов. Проанализированы данные за последние два года $(2019,2020)$. В дополнительном онлайнопросе приняли участие 117 респондентов.

Ключевые слова: экологичность, спортивные мероприятия, пластик, многоразовая посуда.

Received date 05. 10.2020

Accepted date 10.10.2020

Published date 19.10.2020 